\author{
Д. В. Bimep \\ acnipaнm \\ Харківського науково-дослідного інституту судових експертиз імені М. С. Бокаріуса
}

\title{
ДО ПИТАННЯ ОЦІНКИ ВИСНОВКУ ЕКСПЕРТА ПІД ЧАС РОЗСЛІДУВАННЯ ЗЛОЧИНІВ У СФЕРІ ФІНАНСУВАННЯ СОЦІАЛЬНИХ ЦІЛЬОВИХ ПРОГРАМ
}

Під час розслідування злочинів у сфері фінансування соціальних цільових програм експертиза посідає одне із провідних місць у встановленні істини. Це зумовлено тим, що висновок експерта порівняно з іншими доказами має свою специфіку. Незважаючи на те, що висновок експерта - це умовивід, зроблений експертом на основі дослідження наданих матеріалів кримінального провадження із використанням спеціальних знань, він підлягає оцінці слідчим, прокурором, слідчим-суддею, судом тощо, як і інший судовий доказ. Крім того, така оцінка здійснюється ними на основі внутрішнього переконання, яке має грунтуватись на повному, всебічному й неупередженому дослідженні всіх обставин кримінального провадження, як вимагає процесуальне законодавство (ст. 94 КПК) [1].

Оцінку висновку експерта як кінцевого продукту судової експертизи, проведеної під час розслідування злочинів у різних сферах людської діяльності, вивчали такі провідні вчені-криміналісти, як: Н.І. Клименко, В.Г. Гончаренко, М.Я. Сегай, М.В. Салтевський, Р.С. Бєлкін, О.Л. Росинська, O.М. Моїсєєв, В.К. Лисиченко, Р.Л. Степанюк, В.Д. Берназ, М.Г. Щербаковський та інші. У ході своїх досліджень вони торкались застосування спеціальних знань у кримінальному провадженні у формі судової експертизи. Трактування оцінки, у тому числі висновку експерта, як розумової, логічної діяльності пронизує весь процес доказування у науковій літературі, досить обгрунтоване та є загальновизнаним [2, с. 66-67]. Однак оцінка висновку експерта під час розслідування злочинів у сфері фінансування соціальних цільових програм досліджена фрагментарно та потребує свого наукового обґрунтування. Також залишаються невирішеними певні питання, пов'язані із розумінням процесів дослідження, перевірки та оцінки висновку експерта під час розслідування цих злочинів, взаємозв'язком та взаємовідношенням цих дій, їх засобами та методами.

Метою статті є виявлення проблем дослідження, перевірки та оцінки висновку експерта під час досудового розслідування злочинів у сфері фінансування соціальних цільових програм і наведення рекомендацій щодо підвищення ефективності цих дій.

Оцінка доказів тісно пов'язана з їх перевіркою та дослідженням. Формальне визначення цих елементів доказування ускладнюється відсутністю їх чіткого розмежування, оскільки у дослідження та перевірку доказів деякими науковцями вкладаються однакові оціночні процедури, серед яких: аналіз, з'ясування змісту доказу та одержання інших доказів для перевірки його доброякісності [3, с. 37]. 3 точки зору інших, перевірка та дослідження пов'язані із реалізацією практичних дій, коли перевірка ведеться як логічними засобами, так і проведенням необхідних слідчих дій, оперативно-розшукових заходів тощо [4, с. 256].

Необхідно зауважити, що оцінка висновку експерта як джерела доказів під час розслідування злочинів у сфері фінансування соціальних цільових програм має відмінності порівняно 3 аналогічною процедурою оцінки інших видів доказів за цими злочинами, серед яких:

- процес експертного дослідження та отримання фактичних даних експертом, як правило, відбувається за відсутності ініціатора проведення експертизи;

- умовиводи експерта формуються у результаті проведеного дослідження, тому всі процесуальні порушення, які мали місце на етапі підготовки матеріалів для проведення експертизи, можуть привести до недопустимості висновку експерта як джерела доказів;

- результат експертного дослідження завжди є умовиводом, що грунтується на спеціальних знаннях, що відсутні в ініціатора проведення експертизи.

Висновок експерта як окремий вид джерела доказів має певні особливості: експерт повідомляє особі, яка призначила експертизу, фактичні дані, встановлені ним особисто під час проведення дослідження в межах поставлених питань на підставі наявних у експерта спеціальних знань; особі, яка ініціювала проведення такого дослідження, для оцінки висновку не обов'язково мати такі самі спеціальні знання, вона не мусить проводити для перевірки висновку будь-які власні дослідження і встановлювати доказові факти; експерт, формулюючи висновок з проведеного дослідження, здійснює оцінку матеріалів експертизи, але така оцінка не є оцінкою доказів, що входить до прерогативи ініціатора експертизи та суду.

Пункт 17 постанови Пленуму Верховного Суду України від 30 травня 1997 року № 8 зобов'язує суд під час перевірки й оцінки експертного висновку з'ясувати: 
- чи було дотримано вимоги законодавства у разі призначення та проведення експертизи;

- чи не складалися обставин, які виключають участь експерта у кримінальному провадженні;

- компетентність експерта і чи не вийшов він за межі своїх повноважень;

- достатність поданих експертові об’єктів дослідження;

- повноту відповідей на порушені питання та їхню відповідність іншим фактичним даним;

- узгодженість між дослідницькою частиною та висновком експертизи;

- обгрунтованість експертного висновку та його узгодженість 3 іншими матеріалами кримінального провадження [5].

У контексті оцінки висновку експерта розглянемо більш докладно кожний із наведених вище елементів доказування, а саме: дослідження, оцінку та перевірку.

Дослідження висновку експерта найчастіше пов'язують із безпосереднім особистим сприйняттям ініціатора експертизи, як способом ознайомлення, з текстом висновку та наведеним у ньому матеріалом. На переконання М.К. Треушнікова, метою дослідження висновку експерта є з'ясування, пізнання його змісту, витяг відомостей, що містяться в ньому [6, с. 246]. Своєю чергою дослідження висновку експерта створює необхідне підгрунтя для подальшої його перевірки та оцінки.

Метою перевірки висновку експерта є встановлення відповідності отриманих експертом даних, проміжних і кінцевих висновків іншим доказам під час розслідування злочинів у сфері фінансування соціальних цільових програм. Така перевірка здійснюється для встановлення доброякісності висновку експерта як джерела доказів і підтвердження достовірності фактичних даних, що отримані судовим експертом у процесі експертного дослідження. Також подібна перевірка має проводитись, коли виникають протиріччя між даними, що містить висновок експерта, та інформацією з інших джерел доказів. За таких умов перевірка може проводитись шляхом збирання нових доказів, які прямо або опосередковано підтвердять чи спростують дані, що містяться у висновку експерта.

Під час оцінки висновку експерта наведені у ньому дані зіставляються 3 наявними іншими доказами у кримінальному провадженні. Законодавчо визначена (ст. 94 КПК) мета оцінки доказів - встановлення належності, допустимості, достовірності кожного доказу й достатності та взаємозв'язку сукупності зібраних доказів для прийняття відповідного процесуального рішення. Мету оцінки висновку експерта можна розглядати $з$ двох сторін: перша надає можливість використовувати висновок експерта як джерело доказів згідно зі ст. 84 КПК, а інша дає змогу оцінити самі встановлені експертним дослідженням факти як докази, що є підгрунтям встановлення істини у провадженні щодо злочинів у сфері фінансування соціальних цільових програм. 3 огляду на зазначене, можна погодитись із М.Г. Щербаковським, який визначає оцінку висновку експерта як розумову діяльність, що здійснюється для допустимості його як джерела доказів, а також достовірності, належності, допустимості та доказового значення фактів і обставин, що встановлені експертним дослідженням [7, с. 354].

Необхідно підкреслити, що завданнями оцінки висновку експерта під час розслідування злочинів у сфері фінансування соціальних цільових програм є встановлення:

- правосуб'єктності, компетенції та компетентності залученого експерта;

- обгрунтованості та вмотивованості висновку, що базується на його переконливості, науковій та логічній доведеності підсумкових умовиводів;

- відповідності дійсності встановлених фактичних даних, інакше кажучи, їх достовірності;

- належності встановлених у висновку даних, що передбачає їх об'єктивний зв'язок з обставинами злочину;

- інформативності висновку, а саме обсягу відомостей, що він містить, про фактичні обставини злочину, які підлягають визначенню;

- місця висновку серед інших доказів з урахуванням встановлених експертом даних для конкретного провадження.

Висновок експерта як джерело доказів є поєднанням фактичних даних, що є умовиводами експерта, та формами їх вираження, що є процесуальним актом. Це зумовлює необхідність розрізняти його зміст і форму. Зміст включає підсумковий висновок як обгрунтований результат експертного дослідження, що формується на професійній оцінці експерта. Форма, своєю чергою, пов'язана із відповідністю висновку як джерела доказів вимогам процесуального законодавства. Під час розслідування злочинів у сфері фінансування соціальних цільових програм ці обидва компоненти важливі для визнання висновку експерта доказом. Так, якщо кінцеві результати експертного дослідження визнаються недостовірними, що не базуються на науковому дослідженні, то висновок експерта не береться до уваги як джерело доказів. 3 іншого боку, незважаючи на об’єктивність та обгрунтованість висновку експерта, недотримання його форми стає причиною невизнання його судовим доказом.

Саме тому необхідно розрізняти оцінку встановлених у результаті експертного дослідження фактів, що відображені у висновку експерта, та оцінку безпосередньо висновку експерта як процесуального акта. У першому випадку відображені у висновку експерта дані необхідно оцінювати шляхом зіставлення їх з іншими зібраними доказами; 
визначати ступінь повноти проведеного експертного дослідження, наукової обгрунтованості підсумкових висновків; достовірність отриманих експертом результатів; перевіряється дотримання процесуальних вимог щодо призначення та проведення експертизи. У другому випадку висновок необхідно дослідити ізольовано від інших матеріалів конкретного провадження щодо злочину у сфері фінансування соціальних цільових програм та оцінити правильність проведеного дослідження.

Процесуальне законодавство визначає (ст. 94 КПК) суб'єктів оцінки доказів, серед яких: слідчий, прокурор, слідчий суддя або суд, а також зауважує, що кожний доказ підлягає оцінці з точки зору належності, допустимості, достовірності, а сукупність зібраних доказів - для прийняття відповідного процесуального рішення [1]. Поряд із цим у процесуальному законодавстві підкреслено, що правом оцінки висновку експерта наділені всі учасники процесу. Статтею 364 КПК передбачено, що під час судових дебатів обвинувач і захисник вправі оцінювати всі докази в кримінальному провадженні, у тому числі і висновок експерта. Суд може погодитись з оцінкою висновку експерта, яка надана будь-яким учасником процесу, але якщо суд не погоджується із міркуваннями учасників судового процесу щодо висновку експерта, їхня думка про значення умовиводів експерта не враховується.

Узагальнення наукових праць дали змогу дійти висновку, що оцінці висновку експерта притаманна низка положень, які не залежать від виду експертизи, їі складності та особи експерта, а саме:

- свобода оцінки, яка означає, що будь-який висновок експерта не має переваг перед іншими доказами та оцінюється, як і всі інші докази у кримінальному провадженні; на оцінку не має впливати, яким експертом проводилась експертиза (стаж роботи, науковий ступінь, вчене звання, є працівником державної спеціалізованої установи тощо);

- повнота оцінки, яка передбачає аналіз: висновку як документа-джерела доказів; всього процесу та результатів експертного дослідження, що дали змогу сформулювати обгрунтовані висновки-умовиводи; процедури призначення та проведення експертизи як слідчої (розшукової) дії в цілому;

- системність оцінки, коли висновок експерта має бути оцінений у загальній системі доказів, серед яких можуть бути усні повідомлення, письмові документи, висновки інших експертиз, результати різноманітних випробувань, речові докази тощо.

Однак у слідчий практиці виникають порушення зазначених принципів оцінки висновку експерта. Так, має місце немотивоване відхилення висновку експерта, умовиводи якого суперечать версії слідчого, що може бути пов'язане із недостатньою кількістю інформації, якою володів ініціатор екс- пертизи, і для перевірки висновку експерта необхідна додаткова інформація. Крім того, бувають випадки, коли висновок експерта використовують як обов' язкову формальну підставу для прийняття процесуального рішення без залучення іншої інформації для його перевірки та оцінки.

Судова практика свідчить, що здебільшого з усього висновку експерта слідчого та суд цікавлять лише підсумки. Оцінка суб'єктами доказування висновку експерта, як правило, зводиться лише до перевірки повноти цих висновків, їх форми та відповідності іншим доказам конкретного провадження. Ініціатор експертизи і суд здебільшого можуть оцінити лише повноту висновку експерта, перевірити, чи на всі поставлені питання дані відповіді та усвідомити характер цих відповідей. Також вони можуть оцінити дотримання експертом необхідних процесуальних вимог і наявність у висновку всіх необхідних реквізитів.

Тому необхідно підкреслити, що змістом оцінки висновку експерта, як і інших джерел доказів, $€$ визначення його допустимості, автентичності та повноти.

Оцінка допустимості висновку експерта передбачає насамперед встановлення факту дотримання вимог Конституції і кримінального процесуального закону під час призначення та проведення експертизи. Під час оцінки висновку експерта важливим є встановлення правильності його оформлення, наявність усіх передбачених законом реквізитів. Оцінюючи висновок експерта, необхідно визначити, чи були дотримані права обвинуваченого (підозрюваного) під час призначення та проведення експертизи. Забезпечення обвинуваченому можливості реально реалізувати свої права під час проведення експертизи, як свого часу підкреслював М.С. Строгович, - гарантія не тільки забезпечення інтересів самого обвинуваченого, але й успішності і доброякісності проведеної у справі експертизи, достовірності її висновків [8, с. 133]. Якщо постанова про призначення експертизи, а також висновки експертизи були пред'явлені обвинуваченому несвоєчасно, то вирішення питання щодо допустимості такого висновку необхідно вирішувати, виходячи із наявності реальних порушень прав обвинуваченого та можливості їх усунення [9, с. 730].

Оцінка допустимості висновку експерта неможлива без встановлення компетентності експерта. У разі здійснення оцінки відповідності кваліфікації експерта предмету експертизи, інакше кажучи його компетентності, ініціатор експертизи чи суд мають ураховувати відомості про освіту, практичний досвід, стаж роботи за фахом, вузької спеціалізації в межах професії експерта, яка свідчить про його компетенцію. Висновок експерта визнається таким, що не відповідає вимогам закону тоді, коли з нього не може бути встановлено, чи 
має експерт достатні пізнання, необхідні для проведення дослідження.

Оцінюючи висновки експерта, необхідно враховувати, що на їх допустимість впливає допустимість об’єктів, які досліджував експерт. Тому необхідно погодитись із думкою науковців, які стверджують, що завжди має бути перевірена процесуальна доброякісність об'єктів експертного дослідження. Для цього потрібно насамперед установити, чи був законним спосіб їх одержання. Так, речові докази, документи тощо, які надаються експерту, мають бути вилучені в ході якоїсь слідчої дії (огляду, обшуку, виїмки) чи представлені ким-небудь з учасників процесу або сторонніми особами [10, с. 43]. Якщо такі об'єкти будуть визнані недопустимими, то автоматично втрачає цю властивість і сам висновок експерта.

Окреме місце під час оцінки висновку експерта займає оцінка його автентичності, під час визначення якої необхідно враховувати, що автентичність висновку експерта значною мірою залежить від достовірності наукових знань, які має експерт, обгрунтованості застосованої під час експертизи методики. Однак у судовій практиці непоодинокими є випадки, коли наукова обгрунтованість експертної методики ставиться під сумнів кимнебудь з учасників процесу і стає предметом активного обговорення в судовому засіданні. Такі ситуації найчастіше пов'язані із використанням нових методик або тих, які є застарілими і здебільшого не використовуються.

Під час оцінки обгрунтованості висновку експерта необхідно перевірити, наскільки висновок експерта підтверджується проведеними ним дослідженнями. Слід зауважити, що це майже найскладніший момент оцінки, оскільки особам, які не мають спеціальних знань, дуже важко оцінити дані, якими оперував експерт (наприклад, чи є достатньою виявлена експертом сукупність ідентифікаційних ознак почерку).

Велике значення під час оцінки висновку експерта має встановлення його повноти. Аналізуючи повноту висновку експерта, необхідно звертати увагу на: повноту використання матеріалів, наданих експерту; застосування різних методів дослідження, що доповнюють один одного та необхідні для об’єктивної, науково обгрунтованої відповіді на поставлені питання; ретельного опису у висновку ходу виконаної експертом роботи. Повнота висновку експерта визначається також тим, наскільки докладно описана у висновках проведена експертом робота. Експерт має використати всі матеріали, необхідні для надання правильного висновку. У висновку експерта мають міститися відповіді на всі поставлені запитання або мотивована відмова від відповіді на запитання. Така відмова може бути зумовлена недостатністю матеріалів, представлених на дослідження, некомпетентністю експерта i, нарешті, відсутністю належних наукових підстав для вирішення цього питання.

Підсумовуючи викладене вище, слід зазначити, що висновки експерта підлягають оцінці, яка $€$ ініціатором експертизи та судом на загальних підставах. Крім того, в контексті оцінки висновку експерта докладно розглянуто кожний з елементів доказування, а саме: дослідження, оцінку та перевірку. Під час оцінки обгрунтованості висновку експерта підкреслена необхідність перевірки, наскільки висновок підтверджується проведеними експертом дослідженнями. Розглянуто та проаналізовано критерії змісту оцінки висновків експерта (допустимості, достовірності та повноти).

\section{Jimepamypa}

1. Кримінальний процесуальний кодекс України від 13.04.2012 № 4651-VI (зі змінами та доповненнями). Відомості Верховної Ради України (ВВР), 2013, № 9-10, № 11-12, № 13, ст. 88.

2. Белкин Р.С. Собирание, исследование и оценка доказательств. Москва. Наука, 1966. 295 с.

3. Михеенко М.М., Молдован В.В., Шибіко В.П. Кримінально-процесуальне право : навчальний посібник. Київ : Вентурі, 1997. 352 с.

4. Берназ В.Д. Доказування за новим КПК України: поняття, структурні елементи. Актуальні проблеми кримінального права, процесу та криміналістики : матер. IV міжн. наук.-прак. конф., присвяченої 95-річчю 3 дня народж. проф. М.В. Салтевського (м. Одеса, 2 листопада 2012 р.). Одеса : Фенікс, 2012. С. 256.

5. Про судову експертизу в кримінальних і цивільних справах : Постанова Пленуму ВСУ від 30.05.1997 p. № 8. URL: https://zakon.rada.gov.ua/ laws/show/v0008700-97.

6. Треушников М.К. Судебные доказательства : монография. Москва : Городец. 1999. 272 с.

7. Щербаковський М.Г. Проведення та використання судових експертиз у кримінальному провадженні : монографія. Харків : В деле, 2015. 560 с.

8. Строгович М.С. Курс уголовного процесса: Порядок производства по уголовным делам по советскому уголовно-процессуальному праву. Москва : Наука, 1970. T. $2.516 \mathrm{c}$.

9. Панько Н.А. Висновок експерта та його оцінка. Форул права. 2012. № 1. С. 728-733. URL: http:// www.nbuv.gov.ua/ejournals/FP/2012-1/12pnatio.pdf.

10. Орлов Ю.К. Заключение эксперта как источник выводного знания в судебном доказывании (уголовно-процессуальные, криминалистические и логико-гносеологические проблемы) : автореф. дисс. ... д-ра юрид. наук. Москва. 1985. 54 с.

\section{Анотація}

Biтер Д. В. До питання оцінки висновку експерта під час розслідування злочинів у сфері фінансування соціальних цільових програм. - Стаття.

У статті підкреслено, що висновок експерта як окремий вид джерела доказів у провадженнях щодо злочинів у сфері фінансування соціальних цільових програм має певні особливості та наведено їхній перелік. Звернуто увагу на те, що висновок експерта як джерело доказів є поєднанням фактичних даних, які є умовиводами експерта, та форми їх вираження, що є процесуальним актом, наведено відмінності між його змістом i формою, оскільки ці обидва компоненти важливі 
для визнання висновку експерта доказом. Крім того, зауважено, що оцінка висновку експерта як джерела доказів під час розслідування злочинів у сфері фінансування соціальних цільових програм має відмінності порівняно 3 аналогічною процедурою оцінки інших видів доказів за цими злочинами. Висновки експерта підлягають оцінці особою, яка є ініціатором експертизи, та судом на загальних підставах. У контексті оцінки висновку експерта докладно розглянуто кожний з елементів доказування, а саме: дослідження, оцінку та перевірку. Поряд із цим визначено завдання оцінки висновку експерта під час розслідування злочинів у сфері фінансування соціальних цільових програм. Наголошено на необхідності розрізняти оцінку встановлених у результаті експертного дослідження фактів, що відображені у висновку експерта, та оцінку безпосередньо висновку експерта як процесуального акта. Узагальнення наукових праць дали змогу дійти висновку, що оцінці висновку експерта притаманна низка положень, які не залежать від виду експертизи, ïï складності та особи експерта, а саме: свобода оцінки, повнота оцінки, системність оцінки, та наведена ïx характеристика. Підкреслена необхідність під час оцінки обгрунтованості висновку експерта перевірки, наскільки висновок експерта підтверджується проведеними ним дослідженнями. Доведено, що змістом оцінки висновку експерта, як і інших джерел доказів, $€$ визначення критеріїв такої оцінки, а саме: допустимості, автентичності та повноти, наведена їхня розгорнута характеристика.

Ключові слова: висновок експерта, оцінка висновку експерта, проведення дослідження, допустимість, достовірність та повнота висновку експерта.

\section{Summary}

Viter D. $V$. On the issue of assessing the expert's conclusion while investigating crimes in the field of financing social targeted programs. - Article.

The article emphasizes that the expert's conclusion, as a separate source of evidence in criminal proceedings in the field of financing social purpose programs, has certain features and their list is provided.

Attention is drawn to the fact that the expert's conclusion, as a source of evidence is a combination of factual data which are expert conclusions and the form of their expression that is a procedural act, and differences between its content and form, as these two components are important for the recognition of the conclusion expert evidence.

In addition, it was noted that the expert assessment of the expert's conclusion as a source of evidence while crime investigation in the area of financing social targeted programs has differences compared with the similar procedure for assessing other types of evidence for these crimes. Expert conclusions are subject to assessment by person initiating the examination and the court on a general basis. In the context of assessing the expert's conclusion, each of the elements of evidence, namely research, evaluation and verification, is considered in detail. Along with this, the task of evaluating the expert's conclusion during the crime investigation in the field of funding social targeted programs is outlined. It was emphasized on the need to distinguish between the expert assessment findings as reflected in the expert's opinion and the assessment of the expert's conclusion as a procedural act. The synthesis of scientific works has led to the conclusion that the evaluation of the expert's conclusion is characterized by a number of provisions that do not depend on the type of examination, its complexity and the person of the expert, namely: freedom of assessment, assessment completeness of the evaluation systemacy of, and their characteristics. It is emphasized the need to assess the validity of the expert's conclusion, as far as the expert's conclusion is confirmed by the studies he carried out. It is proved that the content of evaluation of the expert's conclusion, as well as other sources of evidence, is to determine the criteria for such an assessment, namely: admissibility, authenticity and completeness, their expanded description is provided.

Key words: expert opinion, evaluation of expert's conclusion, research performing, admissibility, authenticity and completeness of expert's conclusion. 